\title{
PENGARUH PELATIHAN COACHING UNTUK MENINGKATKAN KINERJA SUPERVISOR PADA DIVISI WIRANIAGA DI PT. $X$
}

\author{
Rany Fitriany \\ Universitas Putra Indonesia YPTK Padang, Indonesia \\ Email : ranyfitriany@yahoo.com
}

\begin{abstract}
This study aims to see the effect of Coaching training to improve supervisor performance in the sales division at PT. X. Data collection uses performance scales, interviews and observations. The research design used was The One Group Pretest-posttest Design. Technical statistical analysis to test the hypothesis in this study using paired t-test (paired-sample T-test) and qualitative analysis to describe the effect of Coaching training to improve supervisor performance in the sales division at PT. X. The results of the study show that there is an effect of Coaching training to improve supervisor performance in the sales division at PT. X. (p <0.05). The form of influence is positive, which means that when the sales supervisor of the salesperson at PT X receives coaching training, the performance of the sales supervisor of the salesperson at PT. X gets positive changes related to its performance.
\end{abstract}

Keywords: Coaching training, performance and supervisor

\begin{abstract}
ABSTRAK
Penelitian ini bertujuan untuk melihat pengaruh pelatihan Coaching untuk meningkatkan kinerja supervisor pada divisi wiraniaga di PT. X. Pengumpulan data menggunakan skala kinerja, wawancara dan observasi. Desain penelitian yang digunakan adalah The one Group Pretest-postest Design. Teknis analisis statistik untuk menguji hipotesis dalam penelitian ini menggunakan uji t-berpasangan (paired-sample T-test) dan analisis kualitatif untuk mendeskripsikan pengaruh pelatihan Coaching untuk meningkatkan kinerja supervisor pada divisi wiraniaga di PT. X. Hasil penelitian menunjukkan bahwa ada pengaruh pelatihan Coaching untuk meningkatkan kinerja supervisor pada divisi wiraniaga di PT. X. $\quad(\mathrm{p}<0.05)$. Adapun bentuk pengaruhnya adalah positif, yang artinya ketika supervisor divisi wiraniaga di PT X mendapatkan pelatihan coaching maka kinerja supervisor divisi wiraniaga di PT. X mendapatkan perubahan yang positif terkait kinerjanya.
\end{abstract}

Kata kunci: Pelatihan coaching, kinerja dan supervisor.

\section{PENDAHULUAN}

Pada era globalisasi ini persaingan di dalam dunia bisnis semakin kompetitif. Persaingan tersebut mendorong organisasi agar selalu meningkatkan kinerja sumber daya manusia organisasi. Organisasi berusaha mencapai keunggulan bersaing dengan memaksimumkan kemampuan seluruh anggota organisasi. Dengan adanya kondisi ini perusahaan memenuhi kebutuhan tersebut dengan menjadikan pelatihan sebagai cara untuk mencapai tujuan organisasi. Pelatihan dalam sebuah organisasi adalah sebagai suatu upaya untuk pengembangan sumber daya manusia yang merupakan suatu siklus yang harus terjadi terus menerus dan berkesinambungan. Hal ini terjadi karena organisasi itu harus berkembang untuk mengantisipasi perubahan-perubahan yang terjadi di luar organisasi. Oleh karena itu, kemampuan sumber daya manusia organisasi itu harus terus menerus ditingkatkan seirama dengan kemajuan dan perkembangan organisasi. Untuk 
meningkatkan sumber daya manusia maka salah satu cara yang dilakukan adalah dengan mengadakan pelatihan.

Pelatihan merupakan proses pembelajaran yang melibatkan perolehan keahlian, konsep, peraturan atau sikap untuk meningkatkan kinerja karyawan. Menurut pasal 1 ayat 9 Undang-undang No. 13 Tahun 2003 tentang ketenagakerjaan, pelatihan kerja adalah keseluruhan kegiatan untuk memberi, memperoleh, meningkatkan serta mengembangkan kompetensi kerja, produktivitas, disiplin, sikap dan etos kerja pada tingkat ketrampilan dan keahlian tertentu sesuai dengan jenjang dan kualifikasi jabatan dan pekerjaan. Dalam sebuah pelatihan diciptakan suatu lingkungan dimana para karyawan dapat memperoleh atau mempelajari sikap, kemampuan, keahlian, pengetahuan dan perilaku yang spesifik yang berhubungan dengan pekerjaan. Pelatihan biasanya terfokus pada penyediaan keahlian khusus bagi para karyawan atau membantu karyawan membenahi kelemahan kinerja karyawan tersebut (Simamora, 2006). Pelatihan juga berhubungan dengan efektivitas pekerjaan individu tenaga kerja dan hubungan antar tenaga kerja yang dikembangkan dan merupakan program untuk memudahkan pencapaian tujuan perusahaan. Tujuan pelaksanaan pelatihan adalah agar para pimpinan mendapat pengetahuan tentang sikap dan perilaku tenaga kerja yang diperlukan agar kondisi perusahaan sesuai dengan yang diinginkan.

Salah satu perusahaan yang menjadikan pelatihan sebagai cara untuk mencapai tujuan organisasi dan meningkatkan efektivitas organisasi adalah PT. X. Hal ini dikarenakan bahwa PT. X adalah Perusahaan yang sedang melakukan upaya perubahan dan pengembangan menjadi organisasi yang lebih profesional dan mampu bersaing dalam dunia bisnis yang semakin pesat.

Berdasarkan hasil wawancara yang dilakukan PT. X merupakan perusahaan yang sangat memperhatikan pelatihan untuk meningkatkan kinerja sumber daya manusia. Setiap karyawan akan mengikuti pelatihan sesuai dengan kebutuhan karyawan tersebut. Hal ini tertera dalam sistem penilaian kinerja. Didalam matriks kerja perusahaan PT. X setiap bulan diusahakan untuk mengadakan pelatihan bagi karyawan dengan jenis pelatihan yang berbeda-beda. Sebelum mengadakan pelatihan divisi HRD yang menangani pelatihan di PT. X melakukan pengumpulan data kebutuhan pelatihan di setiap dealer PT. X. Pada awalnya pimpinan dimasing-masing dealer melakukan analisa terlebih dahulu mana karyawan yang akan diberikan pelatihan terlebih dahulu dikarenakan calon peserta pelatihan itu biasanya lebih banyak dibandingkan kuota pelatihan sehingga pada saat melakukan analisa itu tentu mendasari pada kebutuhan pelatihan dari masing-masing personal tersebut. Setelah data didapat maka data tersebut diberikan oleh pimpinan masingmasing divisi kepada pihak HRD termasuk divisi wiraniaga. Divisi wiraniaga merupakan salah satu sumber daya manusia yang memegang peranan penting dalam menjalankan aktivitas di PT. X. Oleh karena itu karyawan divisi wiraniaga harus mempunyai kinerja yang baik dan berkualitas untuk mencapai apa yang menjadi tujuan dari perusahaan.

Untuk itu perusahaan membuat sebuah program pembinaaan wiraniaga trainee yang diberikan kepada karyawan baru divisi wiraniaga. Program pembinaan wiraniaga trainee diperlukan oleh pimpinan atau supervisor sebagai panduan untuk menjalankan pembinaan kepada karyawan baru pada 3 bulan pertama kerja supaya menghasilkan karyawan yang berkualitas dan mampu menjalankan tugasnya sesuai dengan tujuan dan sasaran perusahaan dengan standar kinerja yang ditetapkan.

Namun, beberapa bulan yang lalu program pembinaan wiraniaga ini kurang berjalan dengan lancar dikarenakan supervisor kurang mampu memberikan pembinaan kepada karyawan baru. Hal ini disebabkan karena beberapa orang supervisor baru menjabat beberapa bulan sebagai supervisor sales, sehingga merasa belum cukup handal dan mampu dalam memberikan program pembinaan tersebut. Karena ketidakmampuan supervisor 
wiraniaga dalam memberikan pembinaan kepada karyawan tersebut, Hal ini dianggap menghambat proses pengembangan karyawan wiraniaga.

Berdasarkan uraian tersebut diatas, agar program pembinaan wiraniaga trainee ini berjalan dengan lancar dan supervisor mampu memberikan pembinaan kepada karyawan baru sesuai dengan tujuan perusahaan, peneliti tertarik untuk mengetahui apakah dengan dilakukan pelatihan coaching dapat meningkatkan kinerja supervisor pada divisi wiraniaga di PT "X". Dalam penelitian ini, pelatihan coaching sebagai bentuk intervensi psikologis dalam upaya meningkatkan kinerja supervisor pada divisi wiraniaga di PT "X".

\section{LANDASAN TEORI}

\subsection{Kinerja}

Menurut Mangkunegara (2014) menjelaskan bahwa, "kinerja adalah, "Hasil kerja secara kualitas dan kuantitas yang dicapai oleh seorang karyawan dalam melaksanakan tugasnya sesuai dengan tanggung jawab yang diberikan." Hasibuan (2012) kinerja adalah, "Suatu hasil yang dicapai oleh seseorang dalam melaksanakan tugas-tugas yang dibebankan kepadanya. Kinerja (performance) merupakan indikator yang digunakan untuk mengukur tingkat pengcapaian pelaksanaan suatu program kegiatan yang tergambar melalui pencapaian sasaran, visi misi dan tujuan organisasi. Simamora (2004) menyatakan bahwa kinerja mengacu kepada kadar pencapaian tugas-tugas yang membentuk sebuah pekerjaan karyawan. Kinerja merefleksikan seberapa baik karyawan memenuhi persyaratan sebuah pekerjaan. Dari pengertian-pengertian tersebut diatas, dapat disimpulkan Kinerja adalah pencapaian/prestasi kerja karyawan dalam kegiatan atau aktivitas yang sudah direncanakan sebelumnnya baik kualitas maupun kuantitas yang dicapai dalam melaksanakan tugas kerjanya sesuai dengan tanggung jawab yang diberikan kepadanya dalam jangka waktu tertentu.

Kinerja individu maupun kelompok kerja dalam organisasi menggambarkan kinerja organisasi sesungguhnya. Untuk mencapai standar tertentu yang telah ditetapkan organisasi, ada beberapa hal yang mempengaruhi individu maupun organisasi tersebut mencapai standar kinerja atau hasil kerja tertentu. Menurut Simanjuntak, (2005) kinerja dipengaruhi oleh tiga faktor yaitu:

(1) Kompetensi adalah kemanpuan dan keterampilan individu melakukan kerja yang terdiri atas :

(a) Kemampuan dan keterampilan kerja yang dipengaruhi oleh kebugaran fisik dan kesehatan jiwa individu, pendidikan, akumulasi pelatihan dan pengalaman kerjanya.

(b) Motivation dan etos kerja yang dipengaruhi oleh latar belakang keluarga, lingkungan masyarakat, budaya dan nilai-nilai agama yang dianutnya. Seseorang yang memandang pekerjaan sebagai sebuah beban dan keterpaksaan akan mempunyai kinerja yang rendah, dan sebaliknya, yang memandang pekerjaan sebagai kebutuhan, pengabdian, tantangan dan prestasi, akan menghasilkan kinerja yang tinggi.

(2) Dukungan organisasi. Lingkungan organisasi dalam bentuk pengorganisasian, penyediaan sarana dan prasarana kerja inspeksi, serta kondisi dan syarat kerja mempengaruhi kinerja seseorang. Pengorganisasian dapat memberikan kejelasan, kemudahan dan kenyamanan kerja, kondisi kerja mencakup kenyamanan dan keselamatan kerja serta keamanan dan keharmonisan hubungan industrial.

(3) Dukungan manajemen. Kinerja organisasi dan kinerja individu juga bergantung pada kemanpuan manajerial pimpinan atau manajemen dalam membangun sistem kerja dan hubungan yang harmonis, dan mendunkung pengembangan kompetensi pekerja serta menumbuhkan kompensasi dan memobilisasi seluruh tenaga kerja untuk bekerja secara optimal. Dukungan manajemen dapat dilakukan dengan : 
(a) Mengidentifikasi dan mengoptimalkan pemanfaatan kekuatan, keunggulan dan potensi individu.

(b) Mendorong individu untuk terus belajar meningkatkan wawasan dan pengetahuan.

(c) Membuka kesempatan individu untuk belajar baik melalui pendidikan maupun pelatihan yang diprogramkan.

Menurut Mathis dan Jackson (2002) indikator kinerja dibagi atas empat yaitu:

(1) Kualitas kerja. Menyediakan produk dan layanan yang berkualitas merupakan suatu tuntutan bagi perusahaan agar perusahaan dapat bertahan hidup dalam berbagai bentuk persaingan. Hasil kerja yang ideal juga menggambarkan kualitas pengelola produk dan layanan dalam organisasi tersebut.

(2) Kuantitas kerja. Perusahaan yang dapat memenuhi target yang telah ditetapkan menunjukkan kemampuan perusahaan tersebut dalam mengelola sumber daya yang dimiliki dalam mencapai tujuannya.

(3) Waktu kerja. Kemampuan organisasi untuk menetapkan waktu kerja yang dianggap paling efisien dan efektif pada semua level dalam manajemen. Waktu kerja merupakan dasar bagi seorang karyawan dalam menyelesaikan suatu pekerjaan atau layanan yang menjadi tanggung jawabnya.

(4) Kerja sama dengan rekan kerja. Kerja sama merupakan tuntutan bagi keberhasilan perusahaan dalam mencapai tujuan yang ditetapkan, sebab dengan adanya kerja sama yang baik akan memberikan kepercayaan (trust) pada berbagai pihak yang berkepentingan, baik secara langsung maupun tidak langsung dengan perusahaan.

\subsection{Pelatihan Coaching}

Pelatihan didefinisikan sebagai salah satu upaya sistematis untuk meningkatkan pengetahuan (knowledge), ketrampilan (skills), dan sikap kerja (behaviour) para karyawan melalui belajar (Noe, 2000). Berdasarkan pasal 1 ayat 9 Undang-undang No 13 tahun 2003 Pelatihan kerja adalah keseluruhan kegiatan untuk memberi, memperoleh, meningkatkan serta mengembangkan kompetensi kerja,produktivitas, disiplin, sikap dan etos kerja pada tingkat ketrampilan dan keahlian tertentu sesuai dengan jenjang dan kualifikasi jabatan dan pekerjaan. Menurut Simamora (2006), tujuan pelatihan pada intinya adalah : memperbaiki kinerja, memutakhirkan keahlian para karyawan sejalan dengan kemajuan teknologi, mengurangi waktu pembelajaran bagi karyawan baru agar kompeten dalam pekerjaan, membantu memecahkan masalah operasional, mempersiapkan karyawan untuk promosi, mengorientasikan karyawan terhadap organisasi dan memenuhi kebutuhan pertumbuhan pribadi.

Pelatihan mempunyai andil yang besar dalam menentukan efektivitas dan efisiensi organisasi. Beberapa manfaat dari program pelatihan dan pengembangan adalah (Simamora, 2006) : meningkatkan kuantitas dan kualitas produktivitas, mengurangi waktu belajar yang diperlukan karyawan untuk mencapai standar kinerja yang dapat diterima, membentuk sikap, loyalitas, dan kerja sama yang lebih menguntungkan, memenuhi kebutuhan perencanaan sumber daya manusia, mengurangi frekuensi dan biaya kecelakaan kerja dan membantu karyawan dalam peningkatan dan pengembangan pribadi mereka.

Menurut Gallwey's (dalam wiley dan sons, 2007) coaching adalah proses membuka potensi seseorang untuk memaksimalkan kinerja yang hal ini dapat membantu mereka untuk belajar daripada mereka mengajar. Coaching (Pelatihan/pembinaan) merupakan solusi Pendekatan individual, termasuk pembinaan dan pelatihan, fokus pada keterampilan, pengetahuan, dan kemampuan anggota organisasi (cumming,2005). Berdasarkan pengertian diatas dapat disimpulkan bahwa pelatihan coaching adalah usaha meningkatkan kemampuan individu untuk menetapkan dan mencapai tujuan, meningkatkan hubungan interpersonal, menangani konflik ataupun menunjukkan gaya kepemimpinan tertentu. 
Menurut Law (dalam Wiley dan sons, 2007) kegiatan coaching ini memiliki karakteristik-karakteristik yaitu :

(1). Membuka potensi masyarakat untuk memaksimalkan kinerja.

(2). Pendekatan Fasilitasi yaitu membantu mereka untuk belajar daripada mereka mengajar.

(3). Sebuah pendekatan instuksional yaitu hal yang secara langsung berkaitan dengan perbaikan kinerja dan mengembangkan kemampuan dengan memberikan tutorial atau instruksi.

(4). Meningkatkan kinerja di dalam bekerja dan di dalam kehidupan pribadi yang didukung dengan model coaching berdasarkan pada pendekatan terapi mapan.

Tujuan dari coaching adalah untuk mengiringi atasan menjadi lebih efektif dalam melaksanakan beberapa perubahan seperti misalnya proses integrasi dalam merger maupun saat ada pengurangan karyawan, menandai permasalahan kinerja, atau pada saat mengembangkan kemampuan baru sebagai bagian dari program pengembangan kepemimpinan. Coaching berorientasi terhadap masa depan dan tindakan dibandingkan dengan fokus pada masa masa lalu. Coaching membantu karyawan memahami bagaimana perilaku mereka dapat memberikan kontribusi terhadap situasi yang sedang berjalan.

Menurut Kinlaw (1996) Elemen-elemen yang harus ada dalam proses Coaching adalah :

\section{$>$ Key Values}

Proses coaching adalah manajer dan pemimpin yang berbagi keyakinan tentang:

- Kompetensi manusia.

- Superior performance/ kinerja.

- Nilai-nilai couching/ pembinaan.

Keyakinan ini menumbuhkan pengetahuan yang mengarahkan mereka untuk percaya pembinaan unggul menjadi salah satu fungsi yang paling penting dari manajer dan pemimpin.

Gambar : Elemen-elemen dalam proses coaching

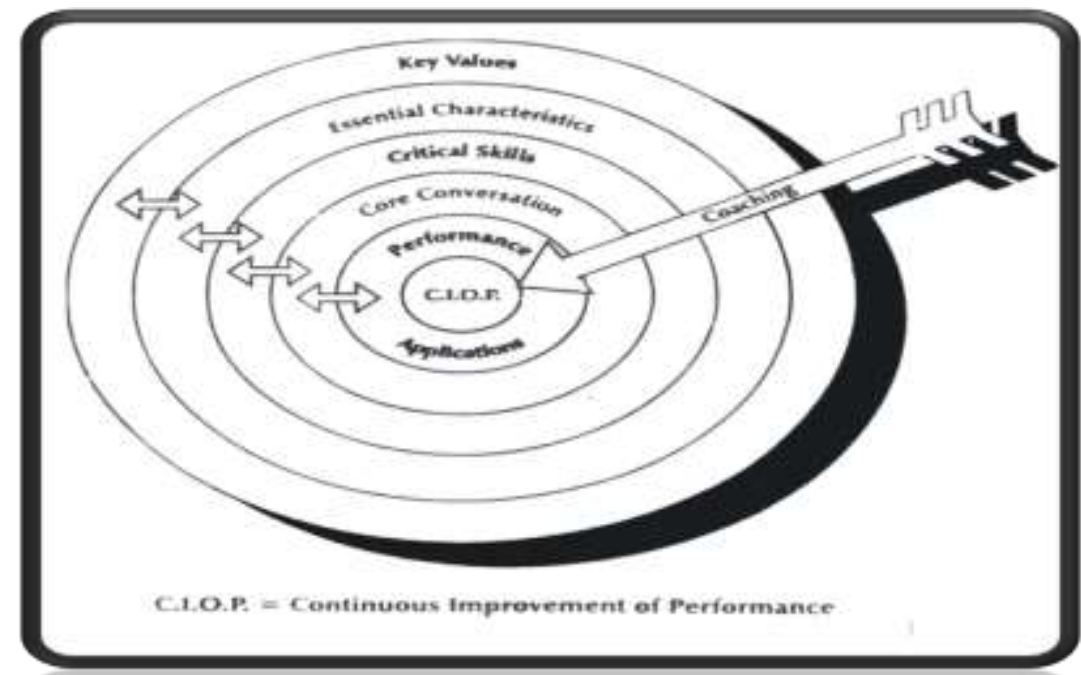

\section{$>$ Essential Characteristics}

Hasil positif dari interaksi coaching/ pembinaan tergantung pada hal berikut:

- Supervisor menciptakan kondisi penting yang mendukung pembinaan.

- Supervisor menggunakan keterampilan yang penting untuk pembinaan. 
- Supervisor cukup disiplin untuk menciptakan struktur dari inti yang mendasari pembinaan.

- Supervisor mampu menerapkan keterampilan dan percakapan inti untuk peluang khusus untuk perbaikan kinerja secara terus-menerus.

\section{$>$ Critical Skills}

Untuk bertindak atas nilai-nilai mereka, supervisor harus menerjemahkan pemahaman mereka tentang pembinaan ke dalam perilaku. Supervisor memiliki keterampilan berikut untuk berinteraksi dengan orang lain:

- Kehadiran

- Inquiry.

- Merefleksikan.

- Menegaskan.

- Menegakkan disiplin.

\section{$>$ Core Conversation}

Salah satu aspek dari menjadi disiplin yang kita inginkan namun belum dikembangkan adalah penggunaan disiplin dari pembicaraan inti. Menjadi disiplin berarti melakukan Model Coaching dalam setiap interaksi pembinaan. Couching merupakan salah satu bentuk pembinaan. Salah satu aspek mayor dari kedisiplinan adalah kemampuan untuk menciptakan bentuk inti pembicaraan. Dengan kata lain pembicaraan yang dilakukan fokus kepada sasaran apa yang akan dikembangkan.

\section{$>$ Performance Application}

Setiap aplikasi kinerja menggambarkan bagaimana inti pembicaraan terlihat dan ide-ide apa yang bisa diterapkan. Hal-hal yang ada didalam aplikasi couching :

- Jalan keluar masalah

- Belajar

- Dukungan terhadap kinerja

- Penyesuaian

\section{METODE PENELITIAN}

Subjek pada penelitian ini berjumlah 10 orang supervisor divisi wiraniaga PT.X. Penelitian ini menggunakan metode Quasi Experiment. Rancangan penelitian berupa one group pretes-posttes design, yaitu menggunakan desain kelompok tunggal dengan prates dan pascates yang dilakukan dengan cara memberikan suatu perlakuan pada satu kelompok tanpa menggunakan kelompok pembanding (Sugiyono, 2012). Dasar pertimbangan memilih desain tersebut karena penelitian ini bertujuan mengetahui perbedaan peningkatan kinerja supervisor antara sebelum pelatihan dan setelah pelatihan.

Metode pengumpulan data yang digunakan untuk melihat perbedaan kinerja supervisor di ukur melalui perbandingan skor skala sebelum pelatihan (prates), setelah pelatihan (pascates) dan tindak lanjut (follow-up) yang diberikan kepada supervisor pada divisi wiraniaga di PT.X. Data dikumpulkan melalui skala kinerja dengan skala model Likert. Prates dilakukan sebelum pelatihan dengan menggunakan skala kinerja guna mengetahui kondisi awal subjek. Pascates dilakukan langsung setelah pelatihan dengan menggunakan skala kinerja. Satu bulan setelah pelaksanaan pelatihan dilakukan tindak lanjut untuk mengetahui apakah masih ada perubahan yang terjadi setelah pelatihan. Pada tindak lanjut ini peserta dibagikan skala yang sama dengan prates dan pascates. Selain itu data juga dikumpulkan dengan dilakukan wawancara dan observasi untuk tiap individu yang mengikuti pelatihan dari awal sampai akhir. 


\section{HASIL DAN PEMBAHASAN}

Analisis hasil penelitian dilakukan secara keseluruhan menggunakan analisa statistik Paired Sample t-test digunakan untuk melihat perbedaan kinerja supervisor sebelum dan sesudah diberikan pelatihan coaching. Berdasarkan data prates dan pasca tes skala kinerja diketahui nilai Sig 0,030 (nilai sig < 0,05) berarti hipotesis diterima, yaitu ada perbedaan kinerja supervisor sebelum pelatihan (Prates) dan setelah Pelatihan Coaching dilakukan (Pascates). Skala kinerja Hasil data prates dan tindak lanjut (setelah satu bulan intervensi) skala kinerja diketahui nilai Sig 0,029 (nilai sig<0,05). Dari sepuluh subjek,mengalami peningkatan dari setelah pelatihan (pascates) dan memiliki konsistensi sampai satu bulan setelah pelatihan coaching (tindak lanjut). Adapun perbandingan skor skala kinerja supervisor pada saat prates, pasca tes dan tindak lanjut dapat dilihat dari gambar dibawah ini :

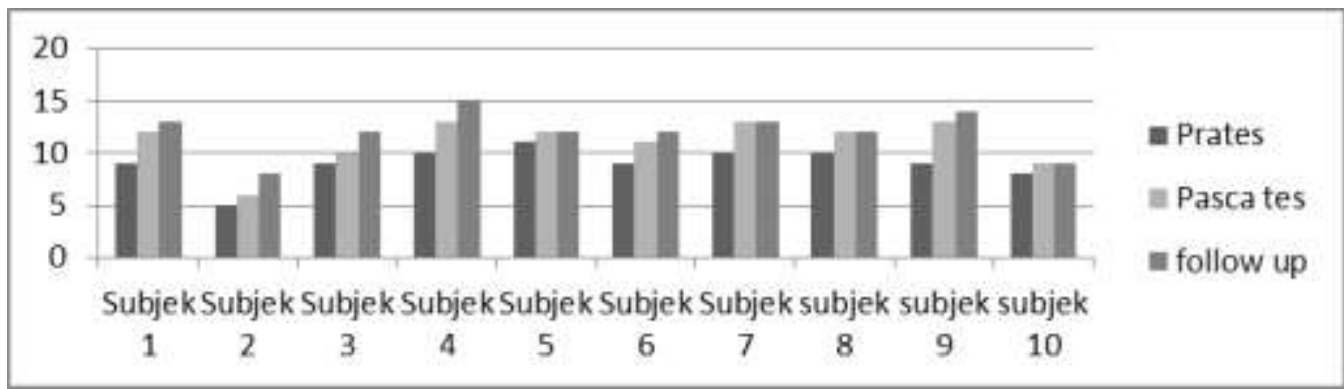

Grafik : Perbandingan skor skala kinerja supervisor prates, pasca tes dan tindak lanjut

Pelatihan coaching yang diberikan dalam penelitian ini adalah untuk meningkatkan kinerja supervisor divisi wiraniaga PT. X. Berdasarkan analisis data prates dan pasca tes yang menggunakan paired sample t-test, diketahui ada perbedaan antara data prates dan data pascates skala kinerja. Hal tersebut menunjukkan kondisi yang berbeda yaitu menggambarkan situasi yang terjadi dimana supervisor memiliki kinerja yang lebih baik dari sebelumnya. Menurut Gallwey's (dalam wiley dan sons, 2007) coaching adalah proses membuka potensi seseorang untuk memaksimalkan kinerja yang hal ini dapat membantu mereka untuk belajar daripada mereka mengajar. Mikky (2001) mengatakan Coaching dapat diartikan suatu proses dimana seorang atasan mampu mengkomunikasikan apa, mengapa dan bagaimana suatu perilaku atau sikap dapat terjadi yang hal tersebut merupakan suatu hambatan dalam melakukan pekerjaan sehingga atasan mampu mendorong karyawan untuk mampu meningkatkan kinerjanya dalam melakukan suatu pekerjaan.

\section{SIMPULAN}

Berdasarkan analisis data dan pembahasan yang dilakukan maka dapat disimpulkan bahwa pelatihan coaching dalam penelitian ini dapat meningkatkan kinerja supervisor pada divisi wiraniaga di PT. X. Supervisor memiliki kemampuan coaching dalam memberikan pembinaan, komunikasi dengan baik sehingga karyawan mampu memahami pembinaan yang diberikan oleh supervisor dan menjalin hubungan interpersonal dengan karyawan sehingga pembinaan dapat dilakukan dengan baik.

\section{REFERENSI}

Arikunto, Suharsimi. 2006. Prosedur penelitian Suatu pendekatan Praktek. Jakarta ; PT. Adi Mahasatya 
Azwar, S. 2012. Penyusunan skala psikologi. Pustaka pelajar : Yogyakarta.

Breiter, D \& Woods, R.H. 1997. An analysis of training budgets anda training needs assessment in mid-sized hotels in the united states. Journal of hospitality \& tourism Research, 21 (2), 86-97.

Chief Editor. 2008. couching dan counseling ; value media . http://indosdm.com/coachingdan-counseling

Cumming \& Worley,2005. Organization Development and change. United State of America : South Western

Irawan, Tjia. 2009. Coaching. http://tjiairawan.com/coaching/

Kinlaw, Dennis. 1996. The ASTD Trainer's Sourcebook: Coaching. USA : Mc Graw Hill Co.

Mangkunegara. 2014. Perencanaan dan pengembangan Sumber daya manusia. Bandung ; PT. Refika Aditama.

Moleong,L.J.2011. Metodologi Penelitian Kualitatif.Bandung: PT.Remaja Rosdakarya

Mikky H. 2001. Coaching, Mentoring and Managing, breakthrough strategies to solve performance problem and build winning team, The U.S.A ; Book-mart Press.

Neo, Raymond A. 2000. Employee training and development. united states ; The McGrawHill Companies

Office of Personnel Management State of Oklahoma. 1999. Performance Management Process Handbook. USA: Personnel Management State of Oklahoma

Sugiyono. 2012. Metode penelitian kualitatif, kuantitatif dan R\&D. Penerbit Alfabeta. Bandung

Pau, Johanes. 2002. Analisis Kebutuhan Pelatihan, Epsikologi, 12 November 2002. Jakarta. Htttp://www.e-psikologi.com/epsi/industri detail. Asp?id=129

Simamora, Hendru. 2006. Manajemen sumber daya manusia. Yogyakarta ; STIE YKPN

The Executive Coaching Handbook. 2004. Principles and Guidelines for a Successful Coaching Partnership Third Edition; The Executive Coaching Forum.

Wiley john \& Son. 2007. The Psychology of coaching, mentoring and learning. England ; the atrium, southern gate, chichester west sussex. Bicentennial.

Gusman, A. P., \& Kurniawan, H. (2018). FUZZY LOGIC DALAM MENGANALISA PENGARUH KONSEP HALAL TOURISM TERHADAP PERILAKU MASYARAKAT SUMATERA BARAT. Jurnal Matematika UNAND, 7(2). 